EASTERN EUROPEAN JOURNAL OF TRANSNATIONAL RELATIONS

2020 Vol. 4 No. 1

DOI: 10.15290/eejtr.2020.04.01.06

Manjola Lumani Zaçellari ${ }^{1}$

Aleksandër Moisiu University of Durrës, Albania

Heliona Miço ${ }^{2}$

Epoka University, Albania

\title{
Parents and Teachers' Involvement in Designing Educational Programmes within the Albanian Curricula of Pre-university Education: Their Perceptions in this Context
}

\begin{abstract}
The purpose of this study is to analyse the legislative measures and their implementation regarding the participation of children, parents and teachers in creating an educational program in pre-university education system, as a need for better involvement in school of all the actors, as well as the need for the children's wellbeing. In addition, the study aims to bring parents' and teachers' views on the obstacles they face when they try to collaborate and participate in school life and in designing an educational program. Qualitative methods are used to achieve the aim of this study. The data were collected through document analysis (legislation, strategies, and regulations) for analysing how the law addresses participation of children, parents and teachers' in school and through semi-structured interviews with parents and teachers from two primary schools so that they can state their perceptions on participation in school life. Each of them was posed 12 different interview questions. After evaluating the responses, some important issues were identified. The participation of children, parents and teachers in Albanian education system has changed in recent years, even promoted as a key that leads to success. However, because of the monist system, where such participation was neither legally recognised nor culturally accepted, this trinomial collaboration has not been easily introduced and integrated in the Albanian educational
\end{abstract}

1 Full-time lecturer in the Department of Albanian Language at Aleksandër Moisiu University of Durrës. She holds a PhD in linguistics. She does research in Linguistics, Didactics, Pedagogy etc. ORCID: 0000-0001-9504-3078. E-mail: manjolazacellari@uamd.edu.al.

2 Lecturer of Law, at "Epoka University" and a researcher in the law and the right to education, educational management, child's rights and social inclusion in education. She has defended her $\mathrm{PhD}$ at the Institute of European Studies, in University of Tirana. ORCID: 0000-0002-23987798. E-mail: heliona.bellani@gmail.com,hmico@epoka.edu.al. 
system. However, parents do not feel very involved in school life, or appreciated when they try to get involved, even though it is legally admitted the need for the collaboration between family and school. They neither take part in the approval of the curricula of the educational institution, nor in the selection of school textbooks as provided by the law. Research has shown that schools as bureaucratic and conservative institutions need to have clear written policies to encourage the participation of the parents and children when drafting an education program. However, when teachers were asked about parents' participation in school, they said that in many cases parents neglect the collaboration with the school and appear usually when there are problems or troubles, while the participation of children in creating an educational program is still lagging behind.

Keywords: participation, children, parents, teachers, legal aspects, Albania

\section{Introduction}

Since the rise of the national school system in the late eighteenth and early nineteenth centuries, nation-states have conceived of general education as designed to install a sense of national identification in the individual. Curricula, designed for this purpose, as well as educational programs have usually consisted of the study of the language, literature, history, government and traditions of the particular nation (Gutek, 1995, p. 5). Later on, the curricula expanded by being liberalized with the introduction of other subjects as an integral part of them. Likewise, the educational programs also changed and were enriched with the insertion of information from different disciplines. The process of the transformation of the curriculum and educational programs in the Albanian education system has passed through the same stages.

According to the Albanian Law on Pre-University Education System, nowadays the curriculum is seen as a system consisting of several elements, such as: curricular framework, core curriculum, educational programs and assessment, which, linked to each other, make the education system oriented and function through educational and administrative plans. An educational program is a program written by the institution or ministry of education, which determines the learning progress of each subject in all the stages of formal education (Definitions.net, n.d.). Program design offers opportunities for educators, students and the community to create educational experiences. The designer brings resources such as learning theories, research studies and program results. The stakeholders bring insight into the program goals, objectives and classroom activities (Dashwood, 2019, para.1).

The curriculum provides qualitative and equal education for every member of the society, regardless of ethnicity, sex, or social position (Law No. 69, 2012). In addition, the curriculum framework is the basic curriculum document which 
describes the aims of the curriculum in general, the core competencies, expected results for students, in terms of knowledge, skills and attitudes at the end of basic and upper secondary education, the aims of the fields of learning and general principles of the teaching and learning process, as well as the students' assessment.

The curriculum consists of a core curriculum, elective curriculum, and the curriculum for complementary activities. The legal provisions have been determined by the Minister of Education as the competent authority to approve the curriculum framework, the educational plan for every level of education, the core curriculum and the subject programs, except for those which are designed by the educational institution. The curriculum, drafted at the educational institution level, is approved by the director of the institution after obtaining consent from the local education institution responsible for pre-university education, it is established by law that the curriculum enables students to make individual choices according to their needs and interests. However, despite the fact that the law sets out clear competences for adapting the core curriculum, the same does not occur for the elective curriculum and the curriculum for complementary activities.

According to the law on pre-university education of 2012, the forms of education in schools are known as:

a) full-time education;

b) part-time education;

c) distance education.

In addition, pursuant to the law, even home-schooling is seen to be offered in special cases for all the classes of basic education or just for some of them. The particular cases, criteria and the procedures for offering education at home shall be determined by the Minister of Education. Even though the law on pre-university education has entered into force in 2012, there have been no further steps taken regarding the manner of providing education conditions for home-schooling.

Meanwhile, now the school is seen as being integrated with the community activity and family life. The main principle is to create a system for all children. This would imply the individualization of teaching to meet the needs of a diverse group of students, in order to become an interactive community (Senge et al., p. 495). The attempts to make parents and children participants in school life are felt even in the pre-university education law of 2012, evidenced by the presence of council of parents, school board, government of pupils, as well as by national council of parents. Regarding the contribution to the school curriculum, this assignment is attributed to the school board. The school board is a body made up of parents, students, teachers, representatives of local government and the community. The board contributes to the wellbeing of the educational institution and reports to the council of parents regarding their activities. The law recognises the approval of the curriculum drafted by the educational institution as the duty of the school board. While on the other 
side, it is still the law which is ambiguous, and does not provide clearly how to deal with elective/optional curriculum and the curriculum for complementary activities, by making unclear the task of the school board towards the curriculum of the school.

\section{Literature Review}

Encouraging the cooperation of parents, teachers and students should be a priority of the country that aims to improve and develop education.

Several studies undertaken to measure the importance of cooperation and involvement of parents, students and teachers in school life indicate that this trinomial collaboration increases the quality of education of a country (e.g. Fantuzzo et al., 2004; Epstein et al., 2002; Gjermani \& Musai, 2008; European Commission, 2005 European Commission, 2001; Levenstein \& Levenstein, 2008; Chang et al., 2009).

Parents' involvement in activities that directly affect the school life of a child serve as a catalyst for achieving high learning outcomes (Child Trends, 2018). In 2018 European schoolnet (2018) issued several recommendations on enhancing collaborative teaching and learning in schools, where among other things it is noted that "collaborative learning has a positive impact on students' academic achievement, as well as on the development of social competences", even though collaborative teaching and learning are not commonplace in schools across Europe yet. At the same time, one of the recommendations relates precisely to engaging parents with school issues. Thus, engaging parents and collaborating with other schools can really facilitate the process of collaborative learning, providing specific training and resources for teaching staff, and developing more flexible classroom spaces to facilitate collaboration (European Schoolnet, 2018).

A volume of a collection of 25 essays, grouped into three parts, on the theme of building bridges between home and school, sheds light on how necessary the involvement of parents in school life is. This aims for the optimization of students' development opportunities, the enhancement of students' educational careers and the improvement of teachers' task performance (Smit et al., 1999).

A report of the European Commission, Evaluation of legislation, policy and practice on child participation in the European Union (2005) emphasizes the effectiveness of participation practices in EU countries. This report compared Albania's legislation, structures and mechanisms for implementing child participation with that of EU member states, the barriers to effective participation, child participation within key sectors, and in relation to vulnerable groups of children which remains a challenge.

Epstein et al. (2002) emphasizes the three spheres of influence where the child mostly learns and develops. The study, defines among other things, the types of 
involvement focusing mostly on family, school and community and are related respectively to: parenting (support the home environment and strengthen families in order to support students at school), communicating (create effective modes of school-to-home and home-to-school communications regarding school programs and child progress), volunteering (recruit parents to support school endeavours), learning at home (share information regarding ideas for learning at home, as well what is going on in the classroom to support family-school alignment regarding educational endeavours), decision making (empower parents to be leaders, and involve them in school decision-making), and collaborating with the community (identify and integrate resources and services from the community to strengthen school programs, family practices, and student learning and development) (Epstein et al., 2002).

Fantuzzo et al. (2004) describe three ways families participate in the education of their children: (a) focused at home, (b) focused at school, (c) focused on communication. According to them, "family involvement in education has been identified as a beneficial factor in young children's learning. It is, therefore, a key component of national educational policies and early childhood programs".

The European report on the quality of school education states "Sixteen quality indicators" (European Commission, 2001), through other factors determine parents' participation and collaboration with teachers as a key factor in order to improve the quality of education. Meanwhile, the report also presents examples of good initiatives to better improve the quality of school education, which can serve as a guide to quality education.

Regarding the Albanian context, parental involvement in school is seen as a very positive process, even though it is not comparable with the European context of parents' participation in school life (Bezati \& Hoxhallari, 2011). In the study Quality of Education Indicators Package, conducted by N. Mita (2002) with the support of AEDP and the Ministry of Education, the involvement of parents is considered as one of the school quality indicators at the institutional school level.

In 2008, a study on the situation of Parents Involvement in Education in Albania by L. Gjermani and B. Musai (2008), supported by UNICEF was conducted. The data for this study was collected through questionnaires and interviews distributed in 12 districts of the country. Questionnaires were drawn up in three types: for parents, for teachers, and for school leaders. The study shows that parental involvement in Albania has reached a significant level of institutionalization through the presence of parents" councils and school boards. However, it is emphasized that "there are still issues in dealing with the effectiveness and self-organization of these parental organisms. In most cases it is noticed that the roles of parents themselves are limited and teachers and school directors are those who have the final word and in some way give a voice to the activity of these parental structures" (Gjermani \& Musai, 2008, p. 10). 


\section{Purpose of the Study}

Given the above-mentioned issues, this study aims to analyse how the law addresses the problem of the participation of children, parents and teachers in creating and planning educational programs aiming to provide a concrete picture of the situation of the current state of parental involvement in school life. Also, the study aims to explore parents' and teachers' views on certain problems they encounter when attempting to participate, collaborate in order to help in improving the children education.

Research questions are formulated as follows:

1. How does the law on pre-university education see the implementation regarding the participation of children, parents and teachers in creating educational programs in pre-university education system?

2. How do parents perceive the participation/ collaboration process with the school and what are the obstacles they face?

3. How do teachers perceive their relationship with parents and does it make them believe that together with the children they form a trinomial structure which serves as a basis for success?

\section{Research Methods}

The data were collected through document analysis (legislation, strategies, and regulations) to examine how the law sees participation of children, parents and teachers' in school and through semi-structured interviews with parents and teachers from two primary schools, aiming to clarify their perceptions on participation in school life. Each of them was posed to 12 different interview questions.

During the administration of the interview process, data collectors explained its purpose, and answered questions from the interviewees to clarify better all the questions asked.

The sample includes 52 parents (who were selected on the basis of different social strata corresponding to different levels of education), and 29 teachers from two public primary schools.

Teacher respondents are females and males, with a representation of $74 \%$ female and 26\% male. According to UNESCO Institute of Statistics in Albania since 2011, $100 \%$ of primary education teachers are women (UNESCO, 2017, p. 137).

Parent respondents are females and males, with a representation of $79 \%$ female and $21 \%$ male.

The researchers of the study adhered to code of conduct and ethical regulations. All respondents were approached in person in order to gain their informed consent on participating in the research study: the aim of the study was explained as well 
as the way the data would be used and published. The confidentiality of the data gathered was guaranteed to the participant.

This study has limitations regarding the findings. These include using in-depth interviews with parents and teachers taken from only two primary schools, which hampers the ability to generalize the data.

\section{Results}

Legal issues regarding the participation of children, parents and teachers in creating education program in pre-university education system in light of the document analysis.

The demand for relevance in education is not a new one. It was the initial impetus for many educational reforms in the past and remains a meaningful plea today (Gutek, 1995, p. 5). This is the reason why educational reforms were necessary in Albania. In addition, the recommendation of the Council of European Union regarding key competences for lifelong learning highlights and promotes the fully involvement of the child in society through the acquisition of the necessary skills (Council Recommendation, 2018). And the involvement of a child in society is done best by involving parents in the educational processes, school decision-making and activities.

The need for parental cooperation for creating an education program arises among others from the growing diversity of Albanian society, which reflects the constant problems during the long transition in Albania. There are cases when families are isolated because of blood feuds, cases of Albanian citizens returning from emigration, or there are times when the families are in very difficult economic conditions which compel the parents to neglect the children. These cases, and others like these, need the partnership of parents, children and teachers to design the appropriate curriculum, adequate to the level and needs of those children.

A typical case of adapting the curriculum according to the needs of the children, beyond the provision of the standard curriculum and the educational programs offered by the state, has been the "Second Chance" curriculum. Through this curriculum, they help the marginalized groups, Roma children, and those who dropped out school and wanted to return to the education system. For this purpose, the Ministry of Education has approved the education program called "second chance", which is offered to all children of school age who have either abandoned or interrupted the learning process or have not attended school at all and do not return to full-time or part-time primary school (Instruction No. 29, 2013, p. 6116). Despite the fact that the teaching is offered by concentrating and abbreviating it more than in the normal teaching process, this education program unlike the standard curriculum has been set 
up to help children who have dropped out of school so as to reintegrate them into the school life (Commission of the European Communities. 2007, p. 14).

The pre-university education law provides that the education system functions on the basis of decentralization and the autonomy of educational institutions. Legal provisions do also guarantee the right of students, teachers and parents to organize themselves into variety of bodies, as well the protection of their rights by assisting in this way in the well-being of the institution. On the other hand, students, educators and parents are given the right to express their views on the quality of educational service and to be heard about these views (Law No. 69, 2012, art. 6).

In order that these legal principles become mandatory, it is imperative to be unfolded throughout the legal framework in force.

The guarantee of autonomy in the law of pre-university education of 2012 was introduced for the first time in the Albanian educational institutions. In this perspective, the parents are considered to be the main partner of the educational institution, playing a vital role in the well-being of the child and the institution. The principle of autonomy, as well as the involvement of children and parents in the school curriculum was incorporated in the board's duties, so as to adapt the curricula drawn up by the educational institution, as well as in the right of the parent to participate in the selection process of school textbooks (Law No. 69, 2012, art. 47). Regarding the children participation, the law provides that this is made possible through organisms such as the student government, which has the function to protect and promote the rights of students and to assist in the well-being of the school.

A more concrete involvement of parents in the designing of an education program is observed in the organization of the education program for children with special needs. In the mainstream educational institutions, for students with special needs a personalized education program is drafted by a committee composed of teachers of various fields and psychologists, in cooperation with the parents of the students. The parents' involvement is also required to change the personalized education program within an educational institution. The parents cooperate with the assistant teacher to design the individual learning plan and the objectives for self-help skills and other social skills that the learner has to reach according to the child's needs (Order No. 343, 2013, art. 97).

\section{The Gaps within the Law}

As emphasized above, the pre-university educational curriculum consists of a core curriculum, elective curriculum and the curriculum for complementary activities. Since the law has provided that the Minister of Education approves only the core curriculum, it is unclear in the law, which body or institution has the right to adapt the optional curriculum and the curriculum for complementary activities in the 
school. In the sub-legal acts, curriculum for complementary activities and elective courses for primary and lower secondary education are seen as a joint planned activity with 1-2 classes per week, despite the fact that the law has organised the pre-university educational curriculum in three categories. While school-based curriculum is only seen in the education plan in upper secondary education, interpreting that part of this curriculum is covered by community service, while the rest includes inter-curricular projects and other school activities (Instruction No. 27, 2018).

According to the Low Secondary Education Guideline of the Institute for Development of Education ${ }^{3}$, the elective curriculum is part of the overall curriculum, which in contrast to the core curriculum is selected by the school and is developed within the scheduled time according to interest of students and school opportunities. This curriculum can be used either for the second foreign language or for subjects, modules or other school activities in order to fulfil the key competencies and the realization of cross-curricular topics. Both of these types of activities are designed by other instances beyond school (Institute for Development of Education, 2017). The Guideline of the Institute for Development of Education hardly fills the gap created by the lack of legal instruments on procedures and the competent body/ organism regarding the designing of the optional curriculum and the curriculum for complementary activities in school.

The law recognizes the right of the educational institution to design subject programs other than those approved by the Ministry of Education (Law No. 69, 2012 , art. 45, point 2, “ç"). However, this right has not been further developed in the law, neither within the scope of the educational institution's duties nor on the rights and duties of the teaching staff. On the other hand, this gap is also found in relation to the competences of the school board. According to the pre-university education law, the school has the right to draft school curriculum which would be approved by the school board (Instruction No. 25, 2018). The changes in the law require that the school curriculum receives the approval of the regional educational directory before the approval of the school director.

Meanwhile the role of school board is unclear in the law. Even though the law confirms on one hand the right of the board (which means even the right of the parents) to give its consent for the school curriculum, on the other hand it is still the law which does not mention the board and parents' involvement.

In the context of parents' involvement in creating an educational program, the education in house conditions, sanctioned in the legal provisions can be mentioned

3 Note: The Institute for the Development of Education conducts research work, provides expertise and advices educational institutions at all levels in the areas of curricular content, didactics and the use of modern teaching technologies, as well as management of school and education as a whole. 
(Law No. 69, 2012, art. 17). Even though the law states that this type of education is offered in special cases, defined by the Ministry of Education, the lack of these guidelines regarding this type of education makes the role of parents unclear in the context of contributing toward an educational program.

In terms of parent involvement in educational curriculum design for children with special needs, the legislation needs to be more detailed about what an individual educational plan must include as well as the actors involved in its formulation and its implementation, while taking into consideration the variety of special needs for the children (NCSE, 2006, p. 1). Such guidelines are not part of the education system in Albania; neither are they part of the procedures and regulations of the Institute for Development of Education ${ }^{4}$. Their presence in the legal framework will facilitate the process of creating and adopting an education program for children with special needs, by clarifying the type of participation.

\section{Parent Views on Participation / Collaboration Process in their Child's School}

In order to explore parents' perceptions of their participation in education, the interviews were focused on the following aspects:

d) Rare visits in children's classrooms, meeting the teachers and discussions with them

e) Lack of participation when decisions are taken, which consequently might affect the child education

f) Lack of participation in creating and developing educational programs

g) Lack of time to participate in school, lack of knowledge on how to participate and lack of sensitiveness from the school system

(a) Rare visits in children's classrooms, meeting the teachers and discussions with them

In the normative provisions of pre-university education, it is seen that teachers hold frequent meetings with parents to discuss various problems regarding their children's progress at school (MES, 2013, art. 84). From the analysis of parents' responses about the frequency of their attendance at meetings with teachers, it turns out that they mostly go to these meetings at the end of each quarter, which coincides with the confirmation of results and grades that their children have taken during that term. In rare cases parents go to their children's school more often, or find other ways to contact the teacher. Meanwhile, after reviewing the annual educational and educational curricula of the school institutions, we have noticed

4 Note: Save the children, prepared in 2017 a Practical Guide to Designing and Implementing an Individual Educational Plan (PEI). 
that the communication and co-operation between the school and the parents is addressed in a special section where meetings are planned with the parents in groups and individually at different intervals throughout the school year. The topic of these meetings, according to the data gathered, is mostly to inform parents about the student's attendance and results, not reflecting any special instruction or advice to help in the development of the students or any specific task that the child might do at home with parent's help.

(b) Lack of participation when decisions are taken, which consequently might affect the child education

From the analysis of the answers it turns out that none of the interviewed parents feels involved when it is the case of making important decisions at school which would affect their child's education process.

According to them, the only opportunity they have to express their views on the wellbeing of their children at school is the parents' meeting.

We as parents are not involved when important decisions are taken about the education of our children. For example, we are not involved in the assessment of textbooks which are supposed to be chosen from school teachers with the participation of parents, nor do we have any means of expressing our disapproval regarding the selection of texts". (R. Z-parent, member of the parents' council)

However, the Albanian law on pre-university education sees that the selection of school textbooks should be done by teachers in the presence of the parents (Order No. 267,2018 ), and in addition the collaboration of parents for drafting a personalised educational program for children with special needs is required.

Other parents admit that there are cases when they are simply asked as a formality to participate and give their opinion on issues affecting children's education and where the decision had been taken before the meeting took place.

"I don't feel included in decisions taken by the school. Sometimes decisions have already been taken without parents' involvement or consent”. (Parent)

According to the instruction on the functioning of the school board of the Ministry of Education (Instruction No. 25, 2018), it is anticipated that when a new teacher (yet not appointed) will work at a specific school and will be part of the staff, the parent as a member of the board of the educational institution should engage and take part in the procedures of his/her recruitment. However, referring to parents' answers who are as well board members declare that this does not happen in reality. 
"I am totally committed to give my opinion and assessment for a new teacher after having enough time to consider his teaching performance, but no one has asked me!". (Parent, member of school board)

\section{(c) Lack of participation in creating and developing educational programs}

One of the questions addressed to the parents during the interviews was related to their involvement in creating and developing educational programs. The answers they give do not directly address the question. Some of them claim that they have given ideas only in terms of extracurricular activities or in choosing topics for discussion in the educational plan. However, most of them claim not to be involved in the compilation or design of an educational program.

On the other hand, the Albanian law on pre-university education recognises the school board as an organism which has the right as well the obligation to approve the curricula of the educational institution.

(d) Lack of time to participate in school, lack of knowledge on how to participate and lack of sensitiveness from the school system

When asked why they did not participate in school parents' meetings, parents mostly answered that it was due to the lack of time. They have to work long hours, especially in the case of divorced parents, family tragedies, and so on, in order to financially support their families.

"I would like to be more engaged in school and help my child more in school activity, but after the death of my spouse I have to work double to ensure a decent living". (Parent)

In some cases, they argue that their lack of participation in school life comes as a result of poor school

welcomed in their children's school, or they do not feel at the right level to be part of the discussions or issues related to the learning activity.

"I have only 4 years of school learning, what kind of thoughts and ideas can I give for my child's education. Teachers know better than me in these cases". (Parent)

In some cases, parents despite their desire to engage in various school activities do not have the proper knowledge on how they can contribute. In fact, the Albanian education system needs to work harder in this regard, because parents, being in many cases unaware of the importance of their participation in school, simply neglect it, seeing the teacher as the only responsible person for educating their children. On the other hand, the school should consider the parental participation as essential to its progress and must become promoter of parental involvement. 


\section{Teachers' Views on their Collaboration with Parents and Children in Creating Educational Program}

Apart from parents' perceptions on participating in the creation of the educational program, a series of interviews with teachers were conducted. The interview questions were focused on the following aspects:

(a) Meeting parents usually when there are problems and trouble with children;

(b) Lack of time to involve parents in useful ways;

(c) Teaching open classes in most times is just a show;

(d) Socio- economic situation and the belonging to an ethnic group or minority hinders parents' participation at school;

(a) Meeting parents usually when there are problems and trouble with children

Involving parents in school activities is one way to make them approach the school and make them part of their child's education, and it provides a helping hand for teachers as well. However, parental involvement is not a simple process, especially given the fact that Albania did not give parents any special roles in the school participation during the communist period. Although today's situation has changed, family-school cooperation is not at satisfactory levels. On the one hand, parents neglect their participation duties and on the other hand, the school does not encourage them to become an active part of the educational program.

During the interviews, the teachers claim that in the majority of cases, parents come to school only when their children have concerns or problems at school (unless parents ask the teacher to get acquainted with the children's performance).

"Some parents come regularly and ask about the progress of children, but a considerable part of them come to school only when there are problems such as troubles or insult among children, and in rare cases when students misbehave or fail to achieve high results". (Teacher)

However, teachers in turn acknowledge that they partially include parents in school life and mostly during the presentation of projects with interesting themes, organization of excursions, when there are children with different abilities, concerts or festivities.

According to the answers of some teachers, there are also even those parents who do not show any interest in their child's education and never contact the teachers or the school director.

"I feel that parents who don't find the time to come to school, don't really care about their children's education. Unfortunately, there are parents who do not know in what grade their child is!". (Teacher) 


\section{(b) Lack of time to involve parents in useful ways}

Teachers are positively affected when parents take an interest in the school. However, most teachers complain about the lack of time, which makes it impossible to engage in a qualitative co-operation with parents and their involvement in school. They are aware that learning as a process does not end in school and that qualitative education also requires parent involvement.

"It is difficult to involve parents in the most efficient way because the time is inadequate, considering that besides teaching we are also committed to completing school documentation". (Teacher)

With the implementation of the new curricula according in the Albanian education system, teachers' responsibilities and duties have changed, adding a great administrative workload. According to teachers, this is a hindering factor not only for co-operation with parents, but in some cases it violates the teaching process as well.

\section{(c) Teaching open classes most of the times is just a show}

At the beginning of 2016, the open classes were introduced in the pre-university education system, being applied initially in the first and sixth grades. During these hours, teachers invite parents and other teachers to organize the learning process together. During these hours, parents have the opportunity to look closely at how their children behave during the lesson, as well as how didactic tools, interactive methods etc. are used. However, some of the interviewed teachers claim that the development of these lessons is just a show, which does not affect the improvement of the teaching process.

"In my opinion open classes are just a show and children do not benefit much as these hours are "pre-prepared" resulting in a "show"; it is not live". (Teacher)

According to teachers, "it would be more productive that inspectors of educational institutions trained in European Union countries, provide good practices and present them to teachers as important experiences to be taken into consideration". (A. D. teacher)

(d) Socio- economic situation and the belonging to an ethnic group or minority hinders parents' participation in school

According to the teachers interviewed, one of the constraining factors of parental participation in school is related to their socio-economic status by being part of an ethnic or minority group. Due to financial difficulties, parents need to work long hours and in some cases they work in two jobs to support their family. That is why they almost do not participate in school life, or do not cooperate with 
teachers in the design of educational programs. On the other hand, parents belonging to ethnic or minority groups tend not to engage in school or various activities of educational character. This indicates that family and school cannot reach effective communication due to cultural diversity.

\section{Discussion}

After the 90s, the Albanian education system has been in a state of constant reform. These reforms have affected all aspects related to the quality of education for generations, aiming at the development of a school that prepares students capable of facing the challenges of life. To prepare successful children for the future, the Albanian school, adapting the European goodwill, has taken important steps in meeting the standards for a qualitative education. However, as a country that has passed a long transition period these standards have not yet been reached because there is still much work to be done.

A very important factor that directly affects the development of education is family-school collaboration. It should be noted that teachers are not just those who cooperate with the students to help them succeed, but parents' participation or co-operation is also a very important factor. However, in the view of parents and teachers cooperation it can still be stated that there are deficiencies and obstacles, which are mainly related to rare visits of parents' in children classroom, lack of participation when decisions are taken affecting children's education, lack of participation in creating and developing educational programs, lack of time to involve parents in useful ways, socio- economic situation of parents and the belonging to an ethnic group or minority that hinders parents' participation in school.

The results suggested are also supported by various studies and reports according to which parents' participation affect students' education. "The way schools care about children is reflected in the way schools care about the children's families. If educators view children simply as students, they are likely to see the family as separated from the school. That is, the family is expected to do its job and leave the education of children to the schools. If educators view students as children, they are likely to see both the family and the community as partners with the school in children's education and development" (Epstein et al., 2002, p. 20701).

Parents, being an active part of school life, giving ideas, supervising, compiling together with their children and teachers' various plans to how their children can succeed in life and face the challenges of the twenty-first century, will lead to a better younger generation who will effectively manage the future. In recent years, education systems worldwide have developed frameworks with an increased emphasis on developing the skills, knowledge, and attitudes necessary for success in the twenty-first century (Saavedra \& Opfer, 2012, p. 4). In this way, parents, and teachers, 
enable students to learn based on powerful new learning modes steeped in real world problem solving (Fullan \& Scott, 2014, p. 6). The skills which a child obtains are now multi-dimensional. But to develop these skills the family-school collaboration is needed.

However, preparing students to face life and its complexity in the twenty-first century is complicated. This is even more complicated in countries which have undergone long transition periods, having economic difficulties, or are post-communist countries such as Albania, which has experienced a severe dictatorship for many years, which affected all spheres of life and undoubtedly education. In the parental involvement in school activities in former communist countries of South Eastern Europe as in Romania, Bulgaria, Macedonia, Bosnia Herzegovina, Croatia, Moldova, Albania, Kosovo, Montenegro and Serbia, their economic status also plays a role. Thus, families with higher socio-economic status feel more efficacious and get involved more in school than those with low socio-economic status (Radu, 2011, p. 103).

In Albania, during the communist years, school rules were strict. The teacher was the main figure for the education of the children, and schooling was a matter belonging to the Party. The younger generation was educated with the love for the party. Moreover, the role of parents was totally neglected, as the children under the care of the Party were only entrusted to the teachers and the school.

After the fall of communism in Albania the transitional period towards a democratic system was accompanied, among other things, with numerous changes in the school and related issues. "Reforming of the educational system in Albania, has experienced fundamental changes in form and content (curricula, school documentation, internal organization of school life), new developments at all levels of the education system (hidden dropouts, problems of vocational education, expansion of general secondary education), decentralization and management of pre-university and higher education, and the teacher's role in the Albanian post-communist society" (Sota, 2014, p. 31).

However, as we have already pointed out parents' participation in school is not at satisfactory levels, especially the participation of parents belonging to different cultures (such as Roma or Egyptian families).

The cultural background affects the relationship between home and school. Henderson and Mapp (2002, p. 15) states that "parents from racial, ethnic and cultural minorities, especially those of low socio-economic status, tend to feel less affinity for the school than those in the mainstream middle class".

Factors affecting parents' lack of participation at school are generated by both the family and the school. Regarding the barriers generated by the family, Drummond and Stipek (2004, p. 197-213) claim that for many families, the barriers to their effective inclusion in school derive from mainly economic difficulties, such 
as low income, poverty and limited levels of parental education, while the barriers generated by the school are mainly related to managerial and administrative aspects.

\section{Conclusions}

The participation of children, parents and teachers in Albanian education system has changed in recent years and is promoted as a successful practice for effective schools. The pre-university education law in Albania provides for the functioning of the education system on the basis of decentralization and autonomy of educational institutions. Legal provisions do guarantee the right of students, teachers and parents to organize themselves into a variety of bodies, which are important for the protection of their rights, assisting in this way in the well-being of the institution. However, despite the legislation in force, after the analysis of the law on pre-university education, instructions, directives and documents we state that these bodies do not function properly and further steps are needed to be taken from the state, in order to make them available. This finding is also supported by the interviewers' responses (parents and teachers) who feel that their participation practices in school need improvement.

On the other hand, children need their voice to be heard (Naseema, 2015), their ideas to be taken seriously and to have the right to the decision-making processes, or to be involved in issues related to their education. For this reason, we strongly believe that schools should change the way they involve their students in education issues. Participation is about giving life to their suggestions and promoting schools that are open to every single idea. Drafting educational programs together with parents and teachers is just one of the varieties of things children can do. Thus, this trinomial collaboration can contribute to establishing effective schools, where everyone is involved and appreciated.

\section{REFERENCES}

Bezati, F., \& Hoxhallari, R. (2011). Përfshirja e prindërve në jetën e shkollës Rekomandime për një partneritet të suksesshëm Shkollë-Familje-Komunitet [Parents' involvement in school life Recommendations for a successful Family-Community Partnership]. Retrieved April 4, 2019 from https://www.osfa.al/sites/default/files/policy_brief_al._pdf.pdf.

Chang, M., Park, B., Singh, K., \& Sung, Y. Y. (2009). Parental Involvement, Parenting Behaviors, and Children's Cognitive Development in Low-Income and Minority Families. Journal of Research in Childhood Education, 23(3), 309-324. https://doi.org/10.1080/02568540909594663.

Child Trends. (2018). Parental Involvement in Schools. Retrieved February 20, 2019 from https:// www.childtrends.org/?indicators=parental-involvement-in-schools. 


\section{EASTERN EUROPEAN JOURNAL OF TRANSNATIONAL RELATIONS}

Commission of the European Communities. (2007, November 6). Commission Staff Working Document. Albania 2007 Progress Report accompanying the Communication from the Commission to the European Parliament and the Council Enlargement Strategy and Main Challenges 20072008 \{COM(2007) 663 final\}. Retrieved from https://eur-lex.europa.eu/legal-content/EN/ TXT/?uri=CELEX\%3A52007SC1429.

Council Recommendation on key competences for lifelong learning (Text with EEA relevance.). (2018, May 22). OJ C 189, 4.6.2018.

Dashwood, T. (2019, May 10). How to design and educational program. Retrieved March 20, 2019 from https://www.theclassroom.com/design-educational-program-8180268.html.

Definitions.net. (n.d.). Educational program. Retrieved March 21, 2019 from https://www.definitions. net/definition/educational+program.

Drummond, K. V., \& Stipek, D. (2004). The elementary school journal; low-income parents' beliefs about their role in children's academic learning. Elementary school Journal, 104(3), 197-213. https://doi.org/10.1086/499749.

Epstein, J. L., Sanders, M. G., Simon, B. S., Salinas, K. C., Jansorn, N. R., \& Van Voorhis, F. L. (2002). School, family, and community partnerships: Your handbook for action (2nd ed.). Thousand Oaks, CA: Corwin Press. Retrieved March 15, 2019 from https://www.govinfo.gov/content/ pkg/ERIC-ED467082/pdf/ERIC-ED467082.pdf.

European Commission. (2001). European report on the quality of school education. Sixteen quality indicators. Luxembourg: European Communities. Retrieved March 10, 2019 fromhttp://aei. pitt.edu/42406/1/A6503.pdf.

European Commission. (2005). Evaluation of legislation, policy and practice on child participation in the European Union. Retrieved March 2, 2019 from http://publications.europa.eu/resource/ cellar/a401df46-7bf6-47dc-bd03-8e2591961614.0001.01/DOC_1.

European Schoolnet. (2018). New European recommendations on enhancing collaborative teaching and learning in schools, Retrieved March 20, 2019 from http://www.eun.org/news/ detail?articleId=1188053.

Fantuzzo, F., McWayne, C.M., Perry, M., \& Childs, S. (2004). Multiple Dimensions of Family Involvement and Their Relations to Behavioral and Learning Competencies for Urban, Low-Income Children. School Psychology Review, 33(4), 467-480. Retrieved February 2, from https://repository.upenn.edu/gse_pubs/438.

Fullan, M., \& Scott, G. (2014). New Pedagogies for Deep Learning Whitepaper: Education PLUS. Seattle, Washington: Collaborative Impact SPC. Retrieved from https://michaelfullan. ca/wp-content/uploads/2014/09/Education-Plus-A-Whitepaper-July-2014-1.pdf.

Gjermani, L., \& Musai, B. (2008). Situata e përfshirjes së prindërve në edukim në Shqipëri [Parents Involvement in Education in Albania]. Tiranë, Shqipëri: UNICEF. Retrieved from http://www. cde.edu.al/sites/default/files/documents/S3-perfshirja_e_Prinderve_SHQIP.pdf.

Gutek, G. (1995). A History of the Western Educational Experience (2nd ed.). Long Grove, IL: Waveland Press, Inc.

Henderson, A.T., \& Mapp, K.L. (2002). A new wave of evidence: The impact of school, family, and community connections on student achievement. Austin, TX: National Center for Family and Community Connections with Schools. Retrieved from https://sedl.org/connections/resources/ evidence.pdf. 


\section{PARENTS AND TEACHERS' INVOLVEMENT IN DESIGNING EDUCATIONAL...}

Institute for Development of Education. (2017). Udhëzues për zhvillimin e kurrikulës së re në AMU (Klasat VI-IX) [Guide for the development of the new curriculum at AMU (Grades VI-IX)]. Retrieved April 2, 2019 from https://ascap.edu.al/wp-content/uploads/2017/04/Udhezues-perAMU-2017.pdf.

Levenstein, Ph., \& Levenstein, S. (2008). Messages from Home: The Parent-Child Home Program for Overcoming Educational Disadvantage. Philadelphia: Temple University Press.

Ligj Nr. 69 "Për Sistemin Arsimor Parauniversitar në Republikën e Shqipërisë” [Law No. 69 "On Pre-University Education System in the Republic of Albania"]. (2012, June 21).

MES. (2013). Dispozitat normative për sistemin arsimor parauniversitar [Normative provisions on Pre-University Education]. Retrieved April 10, 2019 from https://observator.org.al/wp-content/ uploads/2015/11/Dispozitat_normative_per_arsimin_parauniversitar.pdf.

Mita, N. (2002). Paketa e treguesve të cilësisë së arsimit [Package of education quality indicators ]. Vlerësimi i Arsimit, 1(1), 20-88.

Naseema, Sh. (2015). Why children should be seen and heard in school. World Economic Forum. Retrieved April 2, 2019 from https://www.weforum.org/agenda/2015/06/ why-children-should-be-seen-and-heard-in-school/.

NCSE. (2006). Guidelines on the individual education plan process. Dublin: National Council for Special Education. Retrieved from: https://ncse.ie/wp-content/uploads/2014/10/final_report. pdf.

Radu, B.M. (2011). Parental involvement in schools. A study of resources, mobilization, and inherent inequality. Journal of Comparative Research in Anthropology and Sociology, 2(2), 103-115. Retrieved from http://compaso.eu/wp-content/uploads/2011/12/Compaso2011-22-Radu.pdf.

Saavedra, A., \& Opfer, V. (2012). Learning 21st-century skills requires 21st-century teaching. The Phi Delta Kappan, 94(2), 8-13. Retrieved from http://www.jstor.org/stable/41763587.

Save the children. (2017). Udhëzues praktik për hartimin dhe zbatimin e planit edukativ individual (PEI) [Practical Guide to Designing and Implementing an Individual Educational Plan (PEI)]. Retrieved March 22, 2019 fromhttps://albania.savethechildren.net/sites/albania. savethechildren.net/files/library/Udhezues\%20Praktik\%20per\%20Hartimin\%20dhe $\% 20$ Zbatimin\%20e\%20PEI.pdf.

Senge, P.M., Cambron-McCabe, N., Lucas, T., Smith, B., Dutton, J., \& Kleiner A. (2012). Schools That Learn: A Fifth Discipline Fieldbook for Educators, Parents, and Everyone Who Cares About Education. London: Hodder \& Stoughton General Division, Nicholas Brealey Publishing.

Smit, F., Moerel, H., van der Wolf, K., \& Sleegers, P. (Ed.) (1999). Building bridges between home and school. Nijmegen: Institute for Applied Social Sciences, University Nijmegen. (1999). Retrieved May 10, 2020 from http://its.ruhosting.nl/publicaties/pdf/r165.pdf.

Sota, J. (2014). Educational phenomena in Albania in the years of communist dictatorship and the reformation efforts after nineties. European Scientific Journal, 11, 1-46. https://doi. org/10.19044/esj.2011.v11n0p\%25p.

Udhëzim Nr. 25 Ministria e Arsimit, Sportit dhe Rinisë "Për Ngritjen dhe Funksionimin e Bordit të Institucionit Arsimor" [Instruction No. 25 of the Ministry of Education, Sports and Youth "On the establishment and functioning of the board of the educational institution" (2018, July 25)], Retrieved April 20, 2019 from https://arsimi.gov.al/wp-content/uploads/2018/07/UDHEZIM-NR.25-DATE-25.07.2018.pdf. 


\section{EASTERN EUROPEAN JOURNAL OF TRANSNATIONAL RELATIONS}

Udhëzim Nr. 27 Ministria e Arsimit, Sportit dhe Rinisë, Ministria e Financave dhe Ekonomisë për vitin shkollor 2018-2019 në sistemin arsimor parauniversitar" [Instruction No. 27 of the Ministry of Education, Sports and Youth and Ministry of Finance and Economy for the school year 20182019 in the pre-university education system]. (2018, August 16). Retrieved April 20, 2019 from https://arsimi.gov.al/wp-content/uploads/2018/08/Udhezimi-nr.-27-dt.-16.8.2018.pdf.

Udhëzim Nr. 29 Ministria e Arsimit, Sportit dhe Rinisë "Për procedurat e ndjekjes së arsimit bazë me kohë të pjesshme" [Instruction of the Ministry of Education and Science No. 29 "On the procedures for attending part-time basic education"]. (2013, August 2). Retrieved April 12, 2019 from https://www.vet.al/files/ligje\%20etj/2013_2014/udhezim-29-procedura-arsimibaze-kohe-pjesshme.pdf.

UNESCO. (2017). Albania education policy review: Issues and recommendations. Extended Report. Paris: Section of Education Policy (ED/PLS/EDP), Education Sector, UNESCO. Retrieved May, 10, from https://unesdoc.unesco.org/ark:/48223/pf0000259245.

Urdhër Nr. 267 Ministria e Arsimit, Sportit dhe Rinisë "Për përzgjedhjen dhe shitjen e teksteve shkollore të klasave 1,2,3,4,5,6,7,8,9 dhe 10 të sistemit arsimor parauniversitar për vitin shkollor 2018-2019 [Ministry of Education, Sport and Youth. Order No. 267, date: 15.05.2018 on "The selection, distribution and sale of textbooks of grades 1, 2, 3, 4, 5, 6, 7, 8, 9 and 10 of the Pre-university education system for the academic year 2018-2019]. (2018, May 15). Retrieved April 10, 2019 from http://dartiraneqark.edu.al/images/ALTERTEKSTI/ Urdhrinr.267perperzgjedhjeneteksteve-2018-2019.pdf.

Urdhër nr. 343, datë 19.08.2013 i Ministrit të Arsimit dhe Shkencës. Neni 97 i Dispozitave Normative në Sistemin e Arsimit Parauniversitar miratuar nga "Për vitin shkollor 2018-2019 në sistemin e arsimit parauniversitar". [Order no. 343, dated 19.08.2013 of the Minister of Education and Science. Article 97 of Normative Provisions in Pre- university Education System approved by the "In the school year 2018-2019 in the pre-university education system"]. Retrieved from https://arsimi.gov.al/wp-content/uploads/2016/01/PermbledheseUrdheraAPU.pdf.

Vendimi i Këshillit të Ministrave nr. 67 Për Themelimin e Institutit për Zhvillimin e Arsimit (2010, 10 shkurt) [Decision of the Council of Ministers No. 67 On the establishment of the Institute for Development of Education (2010, February 10)]. Retrieved March 20, 2019 from http://www. qbz.gov.al. 